\title{
Teachers and the interactive whiteboards
}

PIROSKA BIRÓ

\begin{abstract}
The spread of IWB (Interactive WhiteBoard) around the world changes, reforms and modernizes the traditional teaching methods. We can find these new ICT devices in more and more schools in Hungary as well and the use of it is getting widespread in everyday teaching. The teachers have the greatest role in the proper use of IWB during the lessons and they are also responsible for providing students with creative and motivating tasks lesson by lesson. In the following research, the advantages of the IWB are highlighted, the difficulties of its usage and the teachers' attitude towards the new ICT devices by asking 205 teachers from different primary and secondary schools. The results are mainly based on questionnaires.
\end{abstract}

Key words and phrases: IWB (Interactive Whiteboard), ICT devices, teaching methods, teachers' attitude.

ZDM Subject Classification: C70, D40, U10.

\section{Introduction}

The appearance of ICT devices revolutionized our life. The IT applications network the world. The lack of technique or its momentary failure can cause huge damage and chaos.

The introduction of ICT devices was opposed, judged and criticized by several people at the beginning but after experiencing its positive aspects they started to use it regularly. The situation is similar in connection with the IWB, a lot of people in Hungary emphasize the disadvantages instead of the positive sides of it. However, it is getting more and more common in classrooms, they are becoming

Copyright (C) 2012 by University of Debrecen 


$$
\text { "tmcs-biro" — 2012/11/25 — 13:58 — page } 282 \text { - \#2 }
$$

part of education and teachers are starting to use it. The first revolutionary teaching tool, the humble blackboard, found its way into classrooms back in 1801 and had a profound impact on the nature of teaching over the next 200 years. The blackboard became synonymous with the traditional classroom and, along with shiny red apples, is still seen as a stereotypical symbol of education. The interactive whiteboard has the potential to be the second revolutionary teaching tool. Just as the blackboard was seen as a key part of nineteenth- and twentieth century classrooms, the IWB has the capability to become synonymous with the new digital classrooms of the twenty-first century (Chris B., Mal L., 2009).

\subsection{What is an interactive whiteboard?}

The first interactive whiteboard was released in 1991, since then the interactive whiteboards have been used in military industry and companies worldwide, and they have also found their way into classrooms.

The interactive whiteboard looks like a white board which is connected to a computer and a projector. With the help of the projector and the various functions of the board, we can see the computer's display on the board and we can control the desktop with our finger or with a special pen.

The interactive whiteboards have several different classifications according to: types of touch (single, dual or multi-touch), the way of control (using mouse, finger, stylus, special pen or other device) or portability (fixed or mobile), or attachable devices, the direction of projecting (front-projection, rear-projection), and technology used (resistive, electromagnetic, infrared optical, laser, ultra-sonic, and camera-based: optical). The dual and multi-touch interactive whiteboards, which can be used by two or more people at the same time, is becoming more and more popular nowadays.

Furthermore, there are some attachable devices that can be connected to the IWB for example: Voting/Response systems, Document Camera, Tablet PCs, Wireless Slates, Audio systems, etc.

\subsection{The use of ICT in Hungary}

The appearance of the interactive whiteboard in the Hungarian primary and secondary schools had a new impulse recently according to several tenders and national research. First of all "The National Development Plan" aimed to install interactive boards in 42000 classrooms (of a total about 62000), however this 


$$
\text { "tmcs-biro" — 2012/11/25 — 13:58 — page } 283 \text { - \#3 }
$$

plan was not fulfilled, and was soon modified, which means that the number of interactive whiteboards and ICT devices was soon changed and reduced.

Another program called "The Intelligent School Program" also helped the spread of IWBs. This is a subprogram of this initiative, which provides a framework for the development of up-to-date public education infrastructure, necessary for gaining and developing the competencies required for lifelong learning and by employers (Tar Zs., 2009).

With the help of further tenders $\left(\mathrm{HRDOP}^{1}, \mathrm{SROP}^{2}, \mathrm{SIOP}^{3}\right)$ and international research every first year BSc students got a laptop in Eszterházy Károly College, Eger in September 2008, thus these students got the opportunity to use ICT devices every day. (Forgó S. et al., 2008). In the meantime, the teacher training school of the college also started a laptop programme in which every fifth-year student got a Classmate PC to use in class and later in their homework assignments. Besides the laptops interactive whiteboards and modern control systems, cameras were also provided for classroom management and digital devices were also given for teacher training. (Nyeste G., 2010).

Thanks to the above mentioned efforts the schools were not just provided with IWBs but with several PCs, projectors and other IWB accessories.

\subsection{Benefits}

The latest scientific studies on the use of the IWB showed that being illustrated or visualized interactively the teaching material can be the key to the success in raising the students' interest and making the learning material more interesting. The IWB is a pedagogic tool and one can achieve success with this method only if it is used in a proper way by the teacher.

The important role of motivation is confirmed by a research made by Keele University. A research team has worked with 12 mathematics departments in partner schools to evaluate the motivational effects of using interactive whiteboards in mathematics classrooms. Although at times it is not easy to separate presentational and motivational effects a number of factors are considered by teachers and pupils to impact upon pupil motivation. Interest and enjoyment were most evident in lessons where the interactive whiteboard, not the teacher, was the focus of the lesson. However, the interactive whiteboard in itself is not

\footnotetext{
${ }^{1}$ Human Resource Development Operative Programme (Hungarian name is HEFOP)

${ }^{2}$ Social Renewal Operative Program (Hungarian name is TÁMOP)

${ }^{3}$ Social Infrastructure Operational Programme (Hungarian name is TIOP)
} 


$$
\text { "tmcs-biro" — 2012/11/25 — 13:58 — page } 284 \text { - \#4 }
$$

sufficient to ensure that pupils are motivated, it is instead the pedagogical stance and the quality of the teaching that enhance motivation (Miller, D., et al., 2004). Cogill J. also confirmed: One who is a great learners themselves, who really strives to get learning across to children and who almost leaps on new resources as a way of engaging, motivating and enthusing children to learn (Cogill, J., 2003).

Other international research also reveal that the most important benefit of the IWB is motivation (Hall, I., Higgins, S., 2005; Glover et al., 2007; Hennessy, S. et al, 2007; Higgins et al., 2007; Jewitt C. et al., 2007; Kennewell, S., Beauchamp, G., 2007; Somekh B., et al., 2007; Cutrim Schmid, E. 2008; Slay et al., 2008; Gillen et al., 2008; Syh-Jong, J. 2010; Troff B., Tirotta R., 2010; Ruth K. et al., 2010).

Clearly the IWB is a lot more exciting than the blackboard and overhead projector, and pupils will be curious to find out about its functions and capabilities. As a result, they may pay more attention than in the past. However, once the teacher has exhausted all the IWB routines, and the 'wow' factor has passed, these pupils may revert to less attentive behaviour (Beauchamp, G., Parkinson, J., 2005).

Further benefits of using the board often mentioned and supported by research in the literature of this field are the following: whole-class teaching, flexibility, versatility (Miller, D., Glover, D., 2002), interactivity and participation is lesson (Heather J. S. et al, 2005; Kennewell S., Beauchamp, G., 2010), group working/cooperation, collaborative learning and knowledge building (Warwick, P., Kersner R., 2008; Ruth K. et al., 2010), multimedia classroom learning (Warwick, P. et al., 2006; Gillen et al., 2008), multimedia/multimodal presentation, efficiency, supporting planning and the development of resources (Heather J. S. et al., 2005), integrating a wide range material from the internet, the teachers can use existing content, virtual learning environment, easy/rapidly learner feedback, save and re-use material, more attractive presentation of materials, improve creativity. It provides greater opportunity for constructive pedagogy, project pedagogy and differential pedagogy.

\subsection{Problems and difficulties}

Using the IWB has not only benefits but there are also some drawbacks and difficulties also arise while using it. One of the most important causes of these problems is the insufficient IT knowledge of the teacher which may place them in a rather unpleasant situation in the classroom. It can be overcome by continual practice (Heather J. S. et al, 2005). Furthermore, the lack of training, support 


$$
\text { "tmcs-biro" — 2012/11/25 — 13:58 — page } 285 \text { - \#5 }
$$

and money are also a problem. It is very difficult to obtain a good quality and cheap digital curriculum.

The drawback of fixed-height boards is that it is difficult for short students and teachers to reach the top half of the board. However another drawback maybe the wrong placement of the projector may also cause shadow, which happens mostly in case of mobile boards. It takes more time to prepare for a lesson, a teacher needs more time to create the materials for the lesson. It often happens that the teacher shares too much information which can be confusing. Teachers sometimes make a mistake by using glittering materials full of animation which may distract students' attention and they miss the main point of the lesson. It takes time and experience to become technically accomplished (Miller, D., Glover, D., 2002).

Summarising the difficulties, we face most of the problems in the first phase of the introduction/use of the device. These are mainly in connection with technical setting, the knowledge of software, handling the device, lack of digital curriculum, lack of experience, the time of preparation. In Hungary it is a slower process than it is in British schools where the new device can be found in every school. Here several educational institutions lack these devices, although at some places it has been used for a couple of years.

\section{Methodology}

The following research is based on the data collected from a lot of primary and secondary schools of Debrecen, the current situation, teachers' attitude to the IWB usage can be analysed and estimated.

\subsection{Research questions}

In this research the quantitative methods are used to study the experience of IWB usage. The aim was to estimate the spread and effectiveness of the usage of IWB and the teachers' attitude while using the new education tool. Other questions and aims:

- Are there any IWB in the classrooms and what are they used for?

- Do they have computers and informatics knowledge?

- Are there any differences between the attitude of genders or age groups towards IWB? 


$$
\text { "tmcs-biro" — 2012/11/25 — 13:58 — page } 286 \text { — \#6 }
$$

- How frequently is it used in different subjects?

- Teachers' positive and negative opinions about IWB usage.

Quantitative test: questionnaires about the present and the usage of IWB at secondary and primary schools.

Statistical analysis: data processing with using SPSS and Microsoft Excel.

\subsection{Sample}

Preceding the writing of this research paper a survey was carried out among the teachers of 16 primary and secondary schools in Debrecen, Hungary in 2009, to find out the research questions.

From 500 questionnaires 205 were filled in. There were schools that refused the co-operation because they didn't have any IWBs and they can't express their opinion about it.

The proportion of sexes in the sample: $18 \%$ men and $82 \%$ women. The youngest is 26 years old and the oldest one is 62 . The average age of the teachers in the sample is 43 .

\subsection{Questionnaire}

The survey is made up of 32 questions, covering four huge topics.

In the first part the personal particulars are given: age, gender, type of school (primary/secondary), the period of teaching, subjects taught.

In the second part the questions related to computer are stated: computer ownership, computer users, length of time spent with the computer, computer skills.

The questions in the third part are in connection with IWBs: interactive whiteboard ownership at school, the frequency of using the device, the type of device at the school, the number of IWB, preparation of digital curriculum, the length of time for preparation, the use of other ICT devices.

The final part closes with attitude analysis: the evaluation of IWB giving positive and negative opinion. 


\section{Results}

\subsection{Using Computers}

Considering the question on the use of computers the results are the following: $99.5 \%$ of the teachers are able to use computers and $96 \%$ of them have at least one computer at their homes. The average time of using a computer is 2 hours and they use the internet for one and the half hours per day. Figure 1 shows that they use the computer especially for word processing, seeking for information, writing and reading e-mails, etc.

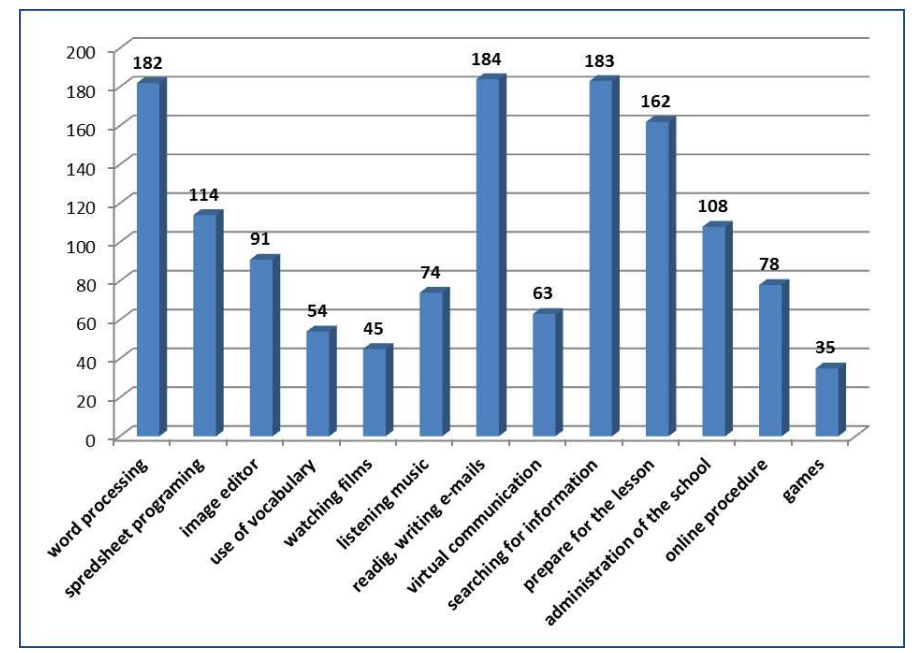

Figure 1. Using the computer

$80 \%$ of the teachers asked use the computer to prepare for classes, which shows that the number of teachers preparing digital material, searching for information on the internet is rising, this way they make the material more colourful and interesting.

According to Figure 2 we can see where they got their knowledge of informatics from, and the result was that the biggest proportion of them learnt it by self-education, which is supposed to be a basic quality of a good teacher to be able to develop him/herself all the time and to be up to date about novelty.

It is important to improve the IT knowledge of the teachers, because of the "gap bridging" which means that the teachers teach the "digital generation" and at a certain point the students have greater IT knowledge, they use the ICT 


$$
\text { "tmcs-biro" — 2012/11/25 — 13:58 — page } 288 \text { — \#8 }
$$

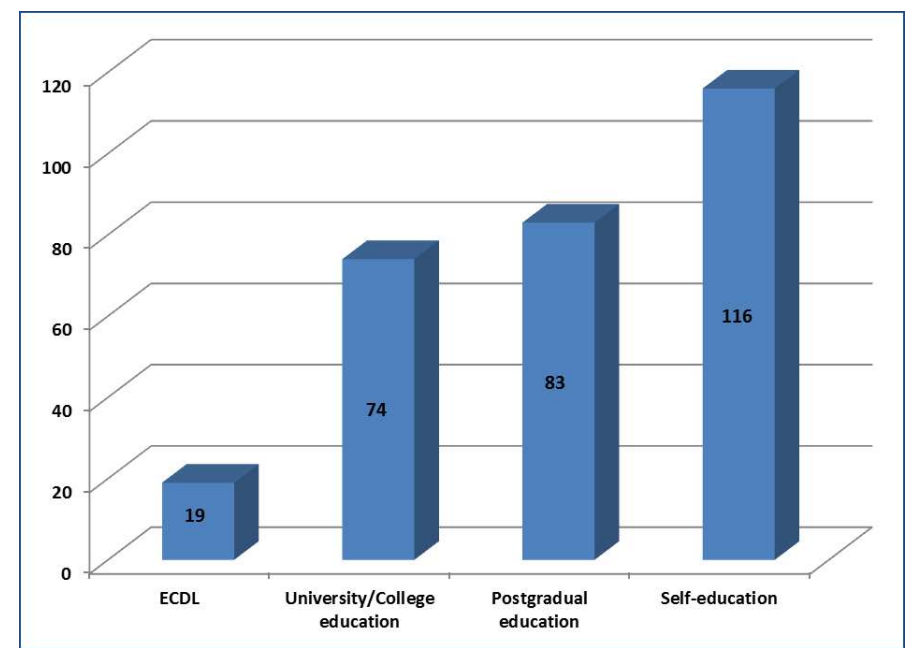

Figure 2. Source of computer knowledge

devices with bigger confidence. According to a survey which was made in 2009 the $84 \%$ of the students at age between 15-24 use the computer and internet regularly on daily basis. (Internet Penetration, 2009). Young people spend long hours searching the web, they use the Internet for communication, and if we could motivate them with this method to search on educational sites or websites related to the teaching material it would be a great benefit for teachers and for students, too.

These ICT devices will be spread in a bigger number in the future and those who use computers with security are scared of getting into unpleasant situation in front of those who have a secure IT knowledge. The lack of time frightens them too, because it takes much more time to prepare for a lesson held with ICT devices.

Figure 3 shows the frequency of the usage of the different ICT devices among the teachers from the sample. The 5 point Likert scale was used to give the answers, where the value 1 meant that they never used ICT devices in teaching and number 5 meant that they often use them.

As we can see the most popular devices are the computer and the printer. 


$$
\text { "tmcs-biro" — 2012/11/25 — 13:58 — page } 289 \text { — \#9 }
$$

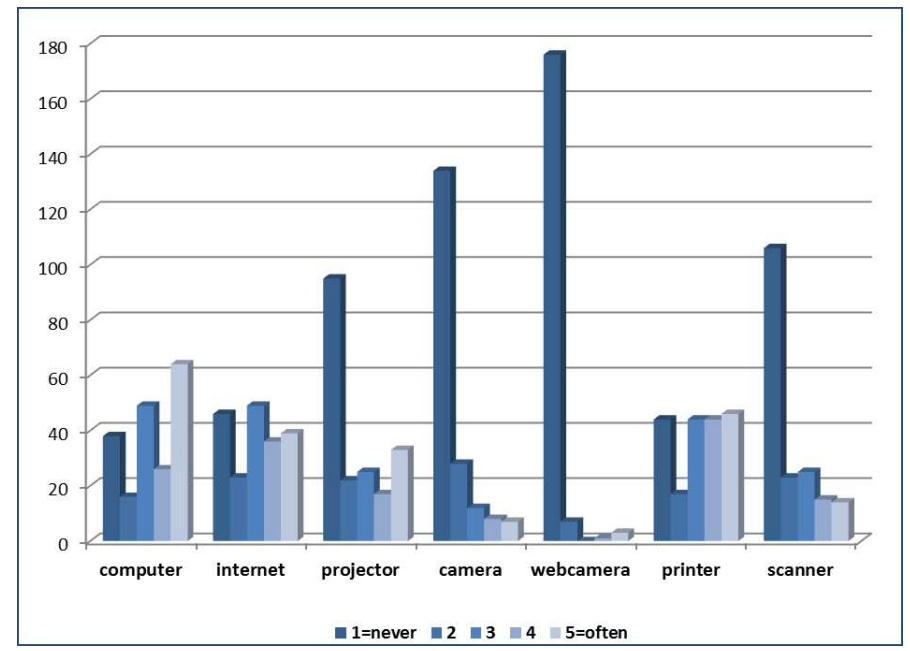

Figure 3. Using ICT devices in education

\subsection{Encountering the IWB for the first time}

There were a number of different answers to my question referring to where they heard about the IWB first. Figure 4 reflects the most frequent answers:

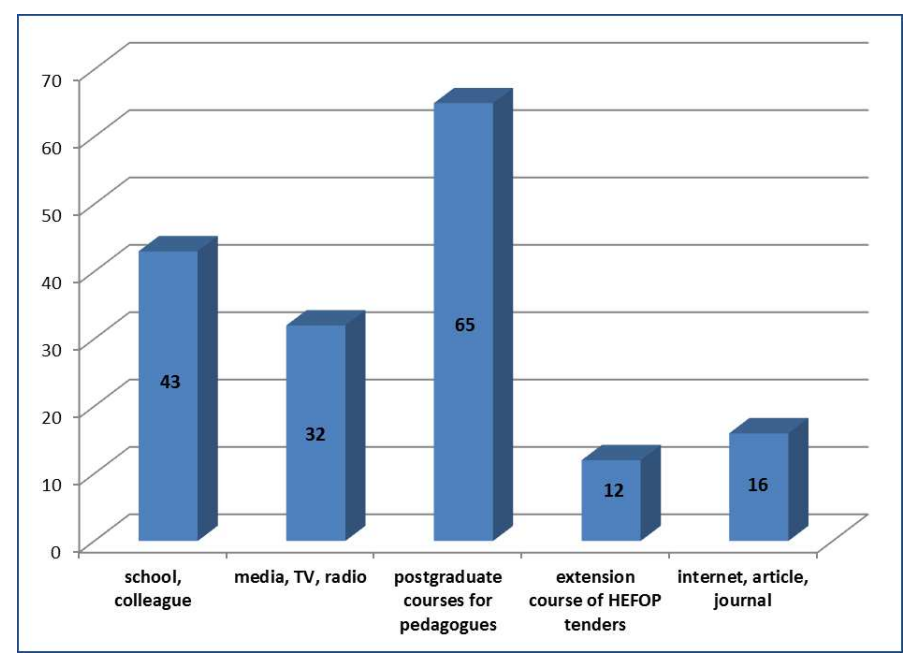

Figure 4. Encountering the IWB for the first time 


$$
\text { "tmcs-biro" — 2012/11/25 — 13:58 — page } 290 \text { — \#10 }
$$

It can be concluded that the new methods and the introduction of devices have become a part of postgraduate courses for pedagogues. In addition different sources of tenders, for example: HRDOP (HEFOP), SROP (TÁMOP) and SIOP (TIOP), have appeared in the schools too, as a consequence of which the teachers got acquainted with and started to use the IWB in their everyday education.

The news of the launch of a new device spread by the media, TV, radio quickly gets to the teachers.

Apart from the above mentioned results, the teachers gave the following answers (less than 10)

- conferences, courses;

- teaching practice;

- language schools, universities;

- program of "Sulinet"

- exhibition of "Jövő háza"

- from the headmasters; etc. .

\subsection{Using Interactive Whiteboard}

After investigating the answers given to the questions referring to the use of the IWB, the results are the following: $70 \%$ of the schools in the sample have min. 1, max. 8 IWB but only $35 \%$ use it in education.

Unfortunately, there are schools where teachers have to use two or three different types of IWBs. It makes the teachers' work more difficult because they have to know all the software. Another possibility is that teachers prepare materials which do not depend on the type of IWB but in this case they cannot use all the options of each IWB software. Several companies are trying to solve this problem, and have been developing independent software and digital curriculum.

The schools which took part in the survey use mainly Mimio, Smart, eBeam and Promethean whiteboards.

One of the negative features of the IWB is that preparing for an IWB-assisted lesson, preparing a digital learning material requires more time, but this time will be saved after a while. The e-teacher-communities help each other by publishing

${ }^{4}$ The Sulinet Program is a digital pedagogical, methodological and professional training for teachers.

${ }^{5}$ House of Future, Budapest 


$$
\text { "tmcs-biro" — 2012/11/25 - 13:58 — page } 291 \text { — \#11 }
$$

their material, and these materials with small modifications and individualizations can be used by other teachers.

Our presumptions seem to be proved: it is difficult to start using the IWB, but it later makes your life easier, so it is worth investing the time first.

The technology seems easier to integrate into existing pedagogic practice and may therefore aid the fuller use of ICT in subject learning. (SWE Project, 2007)

$61 \%$ of the teachers asked say that "First it takes a long time, but later it takes less and less and it helps a lot while preparing for lessons", according to $33 \%$ of them "It takes a long time and preparation every time" and some of them $(6 \%)$ think "It does not take long time".

In Table 1 we can see the time spent on preparing for the lesson among the IWB users and non-users. We did not find any significant difference between the two groups.

The teachers of both groups (IWB users/ IWB non-users) share the same opinion regarding the time needed for the preparation of the digital curriculum. Several teachers did not give an answer in connection with preparing digital curriculum. It suggests that these teachers neither prepare nor use digital sources in their everyday work.

Table 1. IWB usage - Preparing digital curriculum

\begin{tabular}{|c|c|c|c|c|c|}
\hline \multicolumn{2}{|c|}{} & \multicolumn{3}{|c|}{ Preparing digital curriculum } & Total \\
\cline { 3 - 6 } & & $\begin{array}{l}\text { It takes a } \\
\text { long time and } \\
\text { preparation } \\
\text { every time. }\end{array}$ & $\begin{array}{l}\text { First it takes a long } \\
\text { time, but later it } \begin{array}{l}\text { It does } \\
\text { takes less and less and } \\
\text { it helps a lot while } \\
\text { preparing for lessons. } \\
\text { long } \\
\text { time. }\end{array}\end{array}$ \\
\hline \multirow{2}{*}{ IWB usage } & IWB users & 19 & 39 & 2 & 60 \\
\cline { 2 - 6 } & IWB non-users & 10 & 17 & 6 & 91 \\
\hline
\end{tabular}

\subsection{Connections and comparison}

Herein it is investigated whether there is a significant relationship between users of the interactive whiteboard and their gender, age and number of years spent teaching.

In Table 2 we can see the gender distribution of the IWB users. To see the similarities and differences we used the Qhi-Square Test. Table 3 indicates that there is no significant difference between male and female users. We also cannot 


$$
\text { "tmcs-biro" — 2012/11/25 - 13:58 — page } 292 \text { - \#12 }
$$

Table 2. Use of IWB - Gender Cross tabulation

\begin{tabular}{|c|c|c|c|c|}
\hline & \multicolumn{2}{|c|}{ Gender } & \multirow[t]{2}{*}{ Total } \\
\hline & & Man & Woman & \\
\hline \multirow{2}{*}{ IWB usage } & IWB users & 10 & 56 & 66 \\
\hline & IWB non-users & 20 & 101 & 121 \\
\hline \multicolumn{2}{|c|}{ Total } & 30 & 157 & 187 \\
\hline
\end{tabular}

Table 3. Use of IWB - Gender Chi-Square Tests

\begin{tabular}{|c|c|c|c|c|c|}
\hline & Value & $\mathrm{df}$ & $\begin{array}{c}\text { Asymp. } \\
\text { Sig. (2-sided) }\end{array}$ & $\begin{array}{c}\text { Exact } \\
\text { Sig. (2-sided) }\end{array}$ & $\begin{array}{l}\text { Exact Sig. } \\
\text { (1-sided) }\end{array}$ \\
\hline Pearson Chi-Square & $.060^{\mathrm{a}}$ & 1 & .806 & & \\
\hline Continuity Correction $^{\mathrm{b}}$ & .001 & 1 & .971 & & \\
\hline Likelihood Ratio & .061 & 1 & .806 & & \\
\hline Fisher's Exact Test & & & & 1.000 & .491 \\
\hline Linear-by-Linear Association & .060 & 1 & .807 & & \\
\hline $\mathrm{N}$ of Valid Cases & 187 & & & & \\
\hline
\end{tabular}

find any difference if we observe the connection between the number of years spent teaching and the frequency of using IWB.

It is supposed that the IWB is more popular among younger teachers because for them it is easier to acquire the proper knowledge of using modern technology.

We conducted the survey with variance analysis, which is reflected in Table 4 .

Table 4. Using IWB - The number of years spent teaching

\begin{tabular}{|c|c|c|c|c|c|}
\hline & Sum of Squares & df & Mean Square & F & Sig. \\
\hline Between Groups & 7.841 & 35 & .224 & .984 & .502 \\
\hline Within Groups & 33.470 & 147 & .228 & & \\
\hline Total & 41.311 & 182 & & & \\
\hline
\end{tabular}

The sum of squares between groups is by far bigger than the sum of squares within groups. Therefore the value of $F$ will be high and the significance level of the null hypothesis referring to the equal means of the groups. So the alternative hypothesis must be accepted, i.e. there are no significant differences between the group of younger and the group of older teachers.

The IWB was used mainly in this order: mathematics, Hungarian grammar and literature, IT and English lessons. 


$$
\text { "tmcs-biro" — 2012/11/25 — 13:58 — page } 293 \text { — \#13 }
$$

\subsection{Teachers' attitude}

In Table 5 we can see the opinions of the teachers which reflect the negative and positive attitude towards the IWB.

Table 5. IWB usage - Opinions about IWB usage

\begin{tabular}{|c|c|c|c|c|c|}
\hline & \multicolumn{3}{|c|}{ Opinions about IWB usage } & \multirow[t]{2}{*}{ Total } \\
\hline & & Positive & Negative & Positive and negative & \\
\hline \multirow{2}{*}{ IWB usage } & IWB users & 53 & 0 & 7 & 60 \\
\hline & IWB non-users & 64 & 13 & 11 & 88 \\
\hline \multicolumn{2}{|c|}{ Total } & 117 & 13 & 18 & 148 \\
\hline
\end{tabular}

It is interesting that no IWB users said only negative opinion about the tools.

\subsubsection{Positive opinions}

The following opinions show that the teachers are positive in connection with the usage of IWB.

- Makes the acquisition of the material easier, which is more attractive, more expressive and more notable.

- Students can learn and experience lots of things which cannot be learnt from the textbooks, or cannot be presented on the whiteboard. The students will come closer to the subject, it will become more interesting.

- Students pay more attention, more information can be transferred in moments. There are more visual and audible material, faster changing of topic is possible.

- It is advantageous from the aspect of motivation, it results in a various, serious, creative work in lessons.

- Students can approach the knowledge more practically.

- The sounds appear with the animation picture at the same time, like in the environment of the children's home. The students have got used to this visual language, it attracts attention in a more effective way.

- The lesson becomes more playful. The children are mostly influenced by the attraction, they could record lots of things in moments if there was such equipment.

- During the arts lessons we can have children get closer to fine arts.

To summarize the opinions above, we can say that motivation plays a key role in piquing up the interest of students, motivation - rising of inspirations, approach 


$$
\text { "tmcs-biro" — 2012/11/25 — 13:58 — page } 294 \text { — \#14 }
$$

- visual image, group working, project working, interactivity, involvement of more sensual channels, co-operation, ICT competences, etc. We can share the new knowledge more spectacularly and graphically with the students. It gives the opportunity to group and project work. It can make the class more interactive and everybody can take an active part in the learning process. It enhances cooperation between students and teachers and the possibility of improving ICT competencies.

It is very effective when the information gets to the student in different kinds of channels because it is stored and remains better in their minds. For instance the vision, hearing, sensation, sense of feeling etc., because according to a survey, we remember $40 \%$ of things seen and $20 \%$ of things heard, but $75 \%$ of things heard and seen at the same time.

It is interesting that one of my colleagues use dance and rhythm in teaching information technology to help explain algorithms.

\subsubsection{Negative opinions}

Returning to the teachers' opinion they mentioned the following things as negative sides of the device:

- children get used to not learning at home, it needs a lot of time and it is not effective in every occasion.

- the children forget basic knowledge, like writing, reading, counting, because they are not demanded to use them in lessons.

- the children believe that the whole thing is a game and they do not need to learn virtually.

- too expensive, it is got disused fast, problems with compatibility.

- no inspiration for students to write notes.

- the student, after "movie-watching", will not remember anything, if he writes the matter himself, he will remember it better.

- only one student works in front of the board, the others remain passive participants.

\subsection{Barriers}

There is not only a need for teacher training, but also to reform the curriculum in itself. School publishers and companies of subject development are already working in these areas to create new schemes. The diversity of types of interactive 


$$
\text { "tmcs-biro" — 2012/11/25 - 13:58 — page } 295 \text { — \#15 }
$$

whiteboards bundled with different types of programs makes the educator's work fairly difficult.

The use of interactive whiteboards and different ICT devices in a number of schools is common, runs smoothly and there is more and more digital curriculum available for teaching practices.

Currently there are only few IWBs or ICT devices in the schools of Hungary. There is a great need for teacher's postgraduate studies so that they learn how to use the new instruments. There is a need for appropriate digital class material which the teacher makes based on his/her everyday experiences.

The development also involves the improving of devices and programs, we have to follow the change.

Difficulties during the use:

- not enough IWB and ICT devices;

- lack of IT knowledge, the students handle the computer better than the teachers;

- lack of digital contents, electronic curriculum - made by pedagogues;

- fast development - appearance of new equipment and programs, compatibility, technical problems, specific pens, shadow effect;

- lack of time and money;

- finding the right balance the use of IWB;

- finding the solution - how to maximize benefits of the use of IWBs.

\section{Conclusions}

As it is mentioned in the introduction the biggest benefit of the IWB is in the motivational effects. Using ICT devices in the education will lead to some reforms in the teaching methodology. In this new concept the teacher's function will be the cooperative partner's function. The team work between students, the project work will be more emphasized. The students will obtain an active role in the teaching process, the explorative learning and the differentiated teaching, ICT competences will come in to the view.

The importance of the computers can be emphasized with all their benefits we can use during the lessons. Besides the several positive sides we must not forget about the fact that having a computer usually means an internet connection as well which opens a new dimension to the world, which with the appropriate usage of IWB can provide more colourful education. 


$$
\text { "tmcs-biro" — 2012/11/25 - 13:58 — page 296 — \#16 }
$$

The students find the use of the IWB useful in the learning process, it motivates them to understand better the materials, to effectively promote the assimilation of these subject.

The teachers are willing to use the IWB, but because of the lack of these kinds of devices they cannot ensure a quality education with this method.

In this research we can get the answers to the main questions, that the IWB has appeared in the classrooms and where it is available the teachers have started to use it. Most teachers have basic computer knowledge, they are positive and open to use it and the new technological achievements are part of their future conceptions.

Unfortunately, simply putting IWBs in classrooms is no guarantee of success. A good teacher is the most important factor in the teaching. The results are mostly depending on the teacher's personality. This device is one extra thing which the teaching and learning can raise to a higher level in order to help a quality and modern teaching and learning. (Chris B., Mal L., 2009).

\section{References}

[1] G. Beauchamp and J. Parkinson, Beyond the 'wow' factor: developing interactivity with the interactive whiteboard, School Science Review 86, no. 316 (2005), 97-103.

[2] B. Chris and L. Mal, The interactive whiteboard revolution: teaching with IWBs, ACER Press, Australia, 2009.

[3] J. Cogill, How is the Interactive Whiteboard Being Used in the Primary School and How Does This Affect Teachers and Teaching, 2003, Retrieved 2 June 2010, http://www.juliecogill.com/IFS_Interactive_whiteboards_in_the_primary_school.pdf.

[4] E. Cutrim Schmid, Potential pedagogical benefits and drawbacks of multimedia use in the English language classroom equipped with interactive whiteboard technology, Computers \& Education 51, no. 4 (2008), 1553-1568.

[5] S. Forgó, Z. Hauser, L. Kis-Tóth and B. Komenczi, One laptop per student - one laptop per teacher electronic performance support system at Eszterházy Károly College to advance excellent teaching and learning, 2008, Retrieved 12 May 2009, www.agr.unideb.hu/if2008/kiadvany/papers/C62.pdf.

[6] J. Gillen, K. Littleton, A. Twiner, J. Kleine Staarman and N. Mercer, Using the interactive whiteboard to resource continuity and support multimodal teaching in a primary science classroom, Journal of Computer Assisted Learning 24 (2008), 348-358.

[7] D. Glover, D. Miller, D. Averis and V. Door, The evolution of an effective pedagogy for teachers using the interactive whiteboard and modern languages: an empirical 


$$
\text { "tmcs-biro" — 2012/11/25 - 13:58 — page } 297 \text { — \#17 }
$$

analysis from the secondary sectors, Learning, Media and Technology 32, no. 1 (2007), 5-20.

[8] I. Hall and S. Higgins, Primary school students' perceptions of interactive whiteboards, Journal of Computer Assisted Learning 21 (2005), 102-117.

[9] J. S. Heather, S. Higgins, K. Wall and J. Miller, Interactive whiteboards: boon or bandwagon? A critical review of the literature, Journal of Computer Assisted Learning 20 (2005), 91-101.

[10] S. Hennessy, R. Deaney, K. Ruthven and M. Winterbottom, Pedagogical strategies for using the interactive whiteboard to foster learner participation in school science, Learning, Media and Technology 32 (2007), 283-301.

[11] S. Higgins, G. Beaucamp and D. Miller, Reviewing the literature on interactive whiteboards, Learning, Media and Technology 32, no. 3 (2007), 213-225.

[12] Internet Penetration, 2009, Retrieved 15 July 2011, http://nrc.hu.

[13] C. Jewitt, G. Moss and A. Cardini, Pace, interactivity, and multimodality in teacher design of texts for interactive whiteboards in the secondary school, Learning, Media and Technology 32, no. 3 (2007), 303-317.

[14] S. Kennewell and G. Beauchamp, Interactivity in the classroom and its impact on learning, Computers \& Education 54 (2010), 759-766.

[15] S. Kennewell and G. Beauchamp, The features of interactive whiteboards and their influence on learning, Learning, Media and Technology 32, no. 3 (2007), 227-241.

[16] P. Levy, Interactive whiteboards in learning and teaching in two sheffield schools: A developmental study., 2002, Retrieved 13 May 09, http://dis.shef.ac.uk/eirg/projects/wboards.htm.

[17] N. Mercer, Sociocultural discourse analysis: Analysing classroom talk as a social mode of thinking, Journal of Applied Linguistics 1, no. 2 (2004), 37-68.

[18] N. Mercer, The seeds of time: Why classroom dialogue needs a temporal analysis, Journal of the Learning Sciences 17, no. 1 (2008), 33-59.

[19] N. Mercer, L. Dawes, R. Wegerif and C. Sams, Reasoning as a scientist: Ways of helping children to use language to learn science, British Educational Research Journal 30, no. 3 (2004), 359-377.

[20] N. Mercer, P. Warwick, R. Kershner and J. Kleine Staarman, Can the interactive whiteboard help provide 'dialogic space' for children's collaborative activity?, Language and Education 24, no. 5 (2010), 367-384.

[21] D. Miller, D. Glover and D. Averis, Motivation: The contribution of Interactive whiteboards to teaching and learning in mathematics, 2004, Retrieved 12 November 2010, http://www.iprase.tn.it/attivit\%E0/studio_e_ricerca/red5_08/download/03_ Interactive_whiteboard_and_mathematics.pdf.

[22] D. Miller and D. Glover, The interactive whiteboard as a force for pedagogic change: the experience of five elementary schools in an English authority, Information Technology in Childhood Education 1 (2002), 5-19.

[23] G. Moss, C. Jewitt, R. Levačić, V. Armstrong, A. Cardini and F. Castle, The Interactive Whiteboards, Pedagogy and Pupil Performance Evaluation: An Evaluation 


$$
\text { "tmcs-biro" — 2012/11/25 — 13:58 — page } 298 \text { — \#18 }
$$

of the Schools Whiteboard Expansion (SWE) Project: London Challenge, $S W E$ Project, Institute of Education, 2007, Retrieved 3 July 2010, http://www.dcsf.gov.uk/research/data/uploadfiles/RR816.pdf.

[24] G. Nyeste, EKF - a gyakorló iskolától a tanárképzésig, 2010, Retrieved 12 May 2011, http://cmpc.ektf.hu/down.php?presentation=az_iskolai_laptopprogram_eddigi_eredmenyei.ppt.

[25] K. Ruth, M. Neil, W. Paul and K. S. Judith, Can the interactive whiteboard support young children's collaborative communication and thinking in classroom science activities?, Computer-Supported Collaborative Learning 5 (2010), 359-383.

[26] H. Slay, I. Siebörger and C. Hodgkinson-Williams, Interactive whiteboards: Real beauty or just "lipstick"?, Computers \& Education 51 (2008), 1321-1341.

[27] B. Somekh, M. Haldane, K. Jones, C. Lewin, S. Steadman, P. Scrimshaw, S. Sing, K. Bird, J. Cummings, B. Downing, T. H. Stuart, J. Jarvis, D. Mavers and D. Woodrow, Evaluation of the Primary Schools Whiteboard Expansion Project summary report, Report to the Department for Children, Schools and Families, Manchester, England, 2007, BECTA.

[28] J. Syh-Jong, Integrating the whiteboard and peer coaching to develop the TACK of secondary science teachers, Computers \& Education 55 (2010), 1744-1751.

[29] Zs. Tar, Case Study: Hungary - Interactive Whiteboard, 2009, Retrieved 14 August 2011, http://moe.eun.org/c/document_library/get_file?uuid=c4d1dbdb-a98f-47d2a9f $1-9172 \mathrm{fb} 9 \mathrm{~d} 987 \mathrm{f} \& \mathrm{groupId}=10620$.

[30] J. Thompson and M. Flecknoe, Raising attainment with an interactive whiteboard in key stage 2, Management in Education 17 (2003), 29-33.

[31] B. Troff and R. Tirotta, Interactive whiteboards produce small gains in elementary students' self-reported motivation in mathematics, Computers \& Education 54, no. 2 (2010), 379-383.

[32] K. Wall, S. Higgins and H. Smith, The visual helps me understand the complicated things': Pupil views of teaching and learning with interactive whiteboards, British Journal of Educational Technology 36 (2005), 851-867.

[33] P. Warwick, E. Wilson and M. Winterbottom (Eds.), Teaching and learning primary science with ICT, Open University Press, Maidenhead, 2006.

[34] P. Warwick and R. Kershner, Primary teachers' understanding of the interactive whiteboard as a tool for children's collaborative learning and knowledge-building Learning, Media and Technology 33, no. 4 (2008), 269-287.

[35] M. J. Weimer, The influence of technology such as a SMART board interactive whiteboard on student motivation in the classroom, 2001, Retrieved 6 May 2009, http://smarterkids . org/research/paper7 . asp.

PIROSKA BIRÓ

FACULTY OF INFORMATICS

UNIVERSITY OF DEBRECEN

E-mail: biro.piroska@inf.unideb.hu

(Received August, 2011)
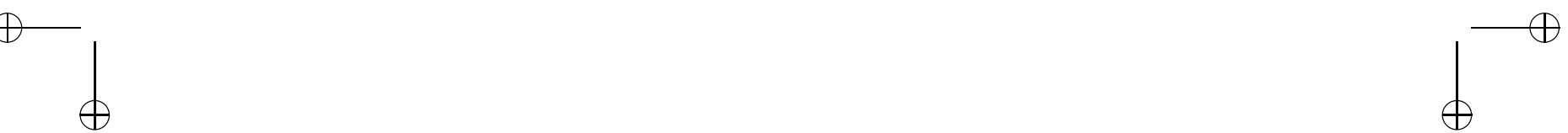